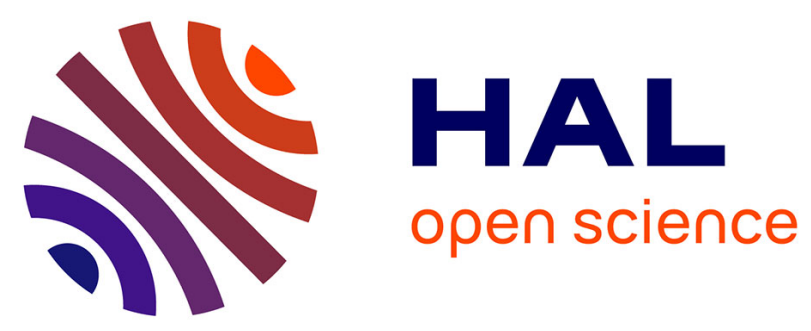

\title{
DISPERSAL OF ECHINODERM LARVAE IN A GEOGRAPHICAL AREA MARKED BY UPWELLING (LIGURIAN SEA, NW MEDITERRANEAN)
}

Ml Pedrotti, L Fenaux

\section{To cite this version:}

Ml Pedrotti, L Fenaux. DISPERSAL OF ECHINODERM LARVAE IN A GEOGRAPHICAL AREA MARKED BY UPWELLING (LIGURIAN SEA, NW MEDITERRANEAN). Marine Ecology Progress Series, 1992, 86 (3), pp.217-227. 10.3354/meps086217 . hal-03284978

\section{HAL Id: hal-03284978 https://hal.science/hal-03284978}

Submitted on 13 Jul 2021

HAL is a multi-disciplinary open access archive for the deposit and dissemination of scientific research documents, whether they are published or not. The documents may come from teaching and research institutions in France or abroad, or from public or private research centers.
L'archive ouverte pluridisciplinaire HAL, est destinée au dépôt et à la diffusion de documents scientifiques de niveau recherche, publiés ou non, émanant des établissements d'enseignement et de recherche français ou étrangers, des laboratoires publics ou privés. 


\title{
Dispersal of echinoderm larvae in a geographical area marked by upwelling (Ligurian Sea, NW Mediterranean)
}

\author{
Maria Luiza Pedrotti, Lucienne Fenaux \\ Laboratoire d'Ecologie du Plancton, Université P. et M. Currie, Observatoire Océanographique de Villefranche-sur-Mer, \\ La Darse, F-06230 Villefranche/Mer, France
}

\begin{abstract}
A spatio-temporal survey of some echinoderm larvae was conducted along a transect of 28 nautical miles from the Bay of Villefranche, France, halfway to Corsica. Distribution patterns and mechanisms responsible for larval dispersal, viz. water currents, hydroclimate and vertical movements, were studied. The echinoderm larvae exhibited weak vertical migration (a few meters), remaining in the surface layer. They are therefore subjected to hydrodynamic constraints which either limit or promote dispersal away from the nursery beds. Larval concentration decreased with distance from the coast and was generally restricted to within 16 miles of the coast. This distance coincided with the location of a coastal divergence zone where rising subsurface waters confined larvae to the Ligurian Current.
\end{abstract}

\section{INTRODUCTION}

At the beginning of the pelagic phase, the horizontal distribution of marine invertebrate larvae corresponds to that of the parents and thus to favorable habitats for settlement (Young \& Chia 1987). Currents and turbulence cause larval transport and dispersal (Okubo 1980). The transport of marine invertebrate larvae by currents has been well studied by Scheltema (1966, 1968, 1971, 1972, 1975, 1986) and Mileikovsky $(1966,1968,1970,1974)$. The larvae may be dispersed and recruited to other distant communities (Thorson 1961, Mileikovsky 1971. Scheltema 1974). For meroplanktonic animals with pelagic planktotrophic larvae, the amount of geographical dispersal increases with the length of larval life and depends upon such factors as swimming behavior and hydrodynamics. Whereas biological interactions appear to be responsible for the horizontal distribution of oceanic zooplankton (Haury 1976, Haury \& Wiebe 1982), physical processes are the principal agents in coastal regions (Haury et al. 1978, Greenblatt 1982, Yamamoto \& Nishizawa 1986). Thus, the spatiotemporal distribution of zooplankton populations, on the medium scale, depends on the movement of water masses, upwelling, convergences and vertical mixing
(Mackas et al. 1985, Boucher et al. 1987, Ebert \& Russell 1988).

In the Côte d'Azur region (French Riviera), the narrow continental shelf limits the bathymetric distribution of neritic echinoderms and consequently restricts the source of planktotrophic larvae strictly to the coast. Some larval production remains near the coast, thereby augmenting its chances of finding nutritive zones for larval growth and settlement, while the remainder is transported by currents into open waters. For neritic invertebrates the major problem is reaching nursery zones conducive to larval settlement and juvenile recruitment.

Under what conditions does larval production result in success? More specifically: What are the mechanisms which retain larvae in coastal environments? Are there ecological barriers which limit larval dispersion towards open waters? Are larvae passive or active in regard to hydrodynamics?

The objective of the present study was to describe the seasonal and temporal variations in the distribution and abundance of echinoderm larval populations and to relate this to processes which determine larval dispersal, viz. currents, temperature and salinity distribution, and vertical and horizontal water movements. Plankton tows were made in the Bay of Villefranche- 
sur-Mer and also along a 28 nautical mile transect perpendicular to the coast between Villefranche and Calvi (Corsica).

\section{STUDY AREA}

The study area was in the Liguro-Provençal Basin in the northeast part of the western Mediterranean. This basin is the center of a cyclonic circulation (Bethoux et al. 1981, Bethoux \& Prieur 1983) induced by largescale integration of climatic factors (evaporation and precipitation) into the general circulation of the Mediterranean Sea (Prieur 1981). Surface waters from the Tyrrenean Sea and the west coast of Corsica form the Liguro-Provençal Current. From the Gulf of Genoa, this current flows westward along the Italian and French coasts. The Ligurian Current occupies a zone stretching from the coast to between 15 and 20 miles offshore; its width varies according to season (Bethoux et al. 1988). The average current flow is on the order of $1.4 \times 10^{6} \mathrm{~m}^{3} \mathrm{~s}^{-1}$ and the average speed in surface layer is $20 \mathrm{~cm} \mathrm{~s}^{-1}$ between 3 and 8 miles offshore and $30 \mathrm{~cm}$ $\mathrm{s}^{-1}$ between 8 and 14 miles offshore (Fig. 1).

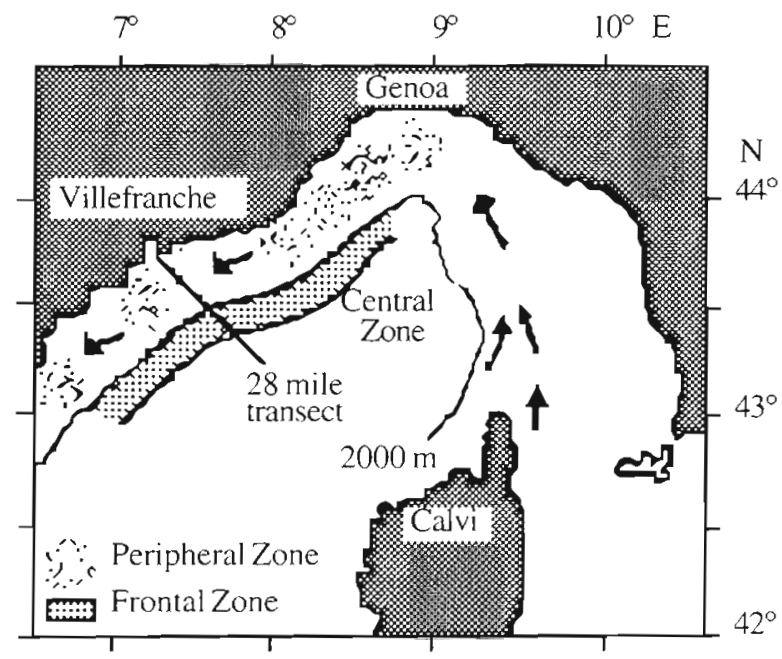

Fig. 1. Schematıc map of the circulation in the LiguroProvençal Basin. The horizontal transect studied is indicated

Hydrological front. Owing to the cyclonic circulation, the surface waters are separated into a central dense homogeneous zone and a less dense peripheral zone. Between these 2 zones a density front is formed marked by very pronounced horizontal density and salinity gradients (Sournia et al. 1990). The mean horizontal density gradient in the frontal zone is higher than in the other zones; the horizontal difference in density near the surface is 0.6 to $1 \mathrm{~kg} \mathrm{~m}^{-3}$ in summer

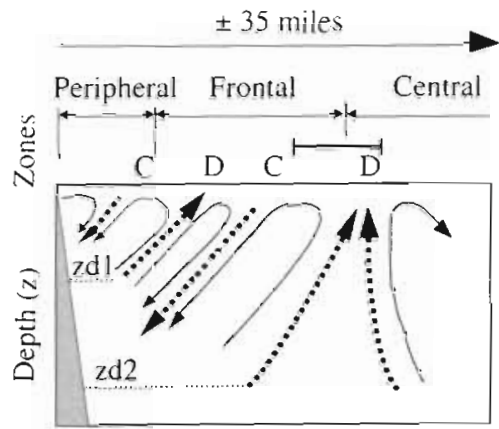

Fig. 2. Schematic representation of the circulation along the transect studied showing the peripheral, frontal and central zones, and convergences (C) and divergences (D). (After Boucher et al. 1987)

and 0.2 to $0.4 \mathrm{~kg} \mathrm{~m}^{-3}$ in winter (Boucher et al. 1987). In the vertical, this front can be recognized by sloping of isopycnal lines and by an active vertical circulation with alternating convergences and divergences (Fig. 2). The hydrological structures of the Ligurian front are permanent; the front is very visible in the surface in winter and early spring, but varies in intensity throughout the year.

Bay of Villefranche. This bay is situated on the northern side of the Ligurian Sea and measures $3.5 \mathrm{~km}$ along its north-south axis (Fig. 3). The $150 \mathrm{~m}$ isobath skirts the entrance to the bay. The depth decreases northward to a sill of $15 \mathrm{~m}$. Surface water masses are regulated by 2 processes: vertical stabilization and homogenization. The bay is subject to the influence of a cyclonic current running from east to west along the

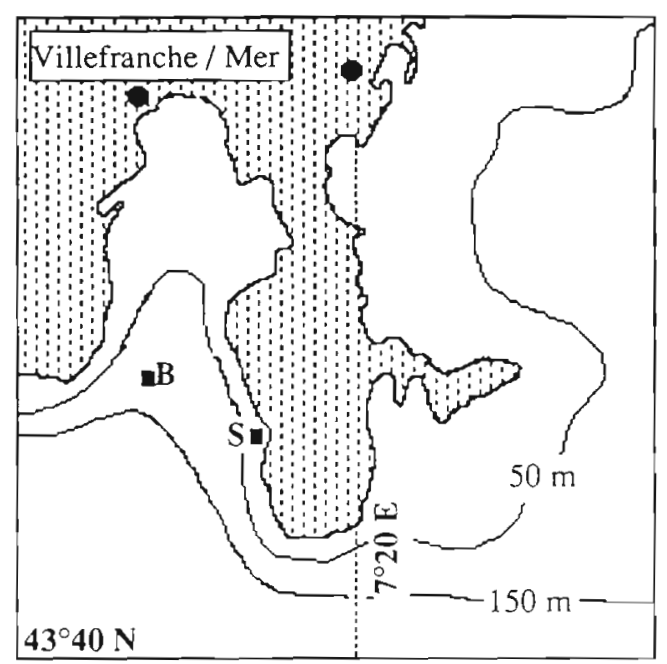

Fig. 3. Locations in the Bay of Villefranche where plankton were collected (Stn S) and salinity and temperature were measured (Stn B) 
Côte d'Azur. Under normal conditions, a branch of the Ligurian Current flowing westward offshore enters the surface of the bay and spreads out northward. Where the depth is greater than $30 \mathrm{~m}$, the current sinks and leaves in an opposite direction to the entry current; where the depth is less, a surface contrary flow is created. Impulses related to the west wind (Mistral) tend to reverse the circulation, pushing the surface mass offshore and replacing it with subsurface water. In the middle part of the Bay the flow is $5 \mathrm{~cm} \mathrm{~s}^{-1}$, and it decreases to $2 \mathrm{~cm} \mathrm{~s}^{-1}$ in the northern part (Hentsch 1959, Nival et al. 1975) (Fig. 4). The thermal stratifica-

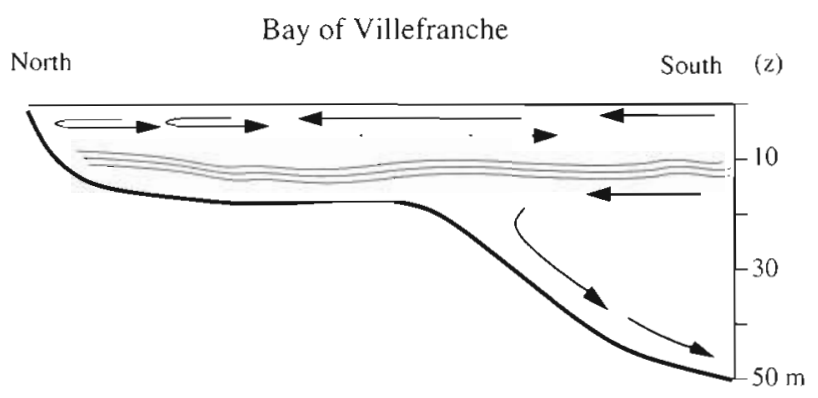

Fig. 4. Vertical section of the Bay of Villefranche showing the circulation in weak wind conditions. A surface current enters the bay and spreads out northward. If depth is greater than $30 \mathrm{~m}$ the current inverses and leaves in an opposite direction to the entry current; if depth is less than $30 \mathrm{~m}$, a surface contrary flow is created. (After Nival et al, 1975)

tion allows nutrients, which enter via urban effluents, to enrich the waters which tend to stagnate in sheltered areas of the bay. This enrichment favors phytoplankton development (Bethoux \& Prieur 1983).

General description of annual variations in temperature and salinity along the Villefranche coast. In the coastal region of Villefranche temperature and salinity data have been collected weekly since 1957 (Stn B; Fig. 3). Between January 1984 and December 1986 at 10,30 and $75 \mathrm{~m}$ depth temperatures ranged from 12 to $24{ }^{\circ} \mathrm{C}$ and salinity from 37.2 to $38.4 \%$. The temperature is homogeneous in winter throughout the water column. From the end of March, it rises progressively, reaching a maximum of $24^{\circ} \mathrm{C}$ in August. The water column is stratified until the end of summer. The temperature then decreases until February of the next year $\left(13.37^{\circ} \mathrm{C}\right.$ on the coast, and $13.5^{\circ} \mathrm{C}$ at 28 miles offshore). In winter, under the influence of a cold, dry continental air mass, the density of the surface water increases, generating vertical mixing of the water column. In February, a zone of high salinity appears between 13 and 18 miles offshore and most likely indicates the leveling off of the intermediate Levantine layer (Gascard 1991), generally situated at $400 \mathrm{~m}$ depth near the coast and $200 \mathrm{~m}$ offshore, and the for- mation of the winter front in the surface. From the end of May, the surface layer begins to stratify. Beginning in August, the 0 to $30 \mathrm{~m}$ layer becomes colder and denser, and there is a tendency towards the formation of a homogeneous layer.

\section{MATERIAL AND METHODS}

Spatio-temporal surveys of echinoderm larvae began with the analysis of samples collected by the research vessel 'Korotneff' between March 1984 and February 1985, and during 1986 along the 28 mile transect from Stn B at Villefranche halfway to Calvi (Corsica). To these series plankton tows were added, starting in September 1986, at Stn S in the Bay of Villefranche.

Plankton tows. At all stations, tows were made with a $200 \mu \mathrm{m}$ mesh net. In the bay, 5 vertical tows $(30$ to $0 \mathrm{~m}$ ) were made each week. During 1984 and 1985 , vertical tows $(200$ to $0 \mathrm{~m}$ ) were taken along the transect twice a month at 6 stations, 5 miles apart. In 1986, horizontal tows were made with a high speed Hai sampler (Boucher 1984) modified by Fenaux \& Pedrotti (1988). Plankton was collected continuously at $10 \mathrm{~m}$ depth. An inboard peristaltic pump brought the animals from the net collector to 2 sampling schemes alternatively. Each sample corresponded to $5 \mathrm{~min}$ of pumping with an average ship speed of 5 knots (i.e. a horizontal distance of about $750 \mathrm{~m}$ ). Between February and June tows were made from the Bay of Villefranche to 11 miles offshore (about 30 samples were preserved during each trip); between July and December samples were taken from the Bay to 28 miles out (about 70 samples were made during each trip). The depth was chosen after statistical analysis of vertical tows showed that abundant larvae were to be found in the first $10 \mathrm{~m}$ (Pedrotti 1990).

Salinity, temperature, and pressure measurements were made with a 8705 Guildline CTD probe from $800 \mathrm{~m}$ to the surface (PROS VI program; Prieur et al. 1990). During zooplankton collection with a pump net, the temperature was also constantly measured using a probe attached directly to the sampler at $10 \mathrm{~m}$ depth. Salinity samples were also collected every $750 \mathrm{~m}$ and measured using a conductivity salinometer (Autosal 8400). Densities were calculated, using the Unesco formula, from temperature and salinity and presented as density excess, which shows the excess density of sea water compared to $1000 \mathrm{~kg} \mathrm{~m}^{-3}$ water.

The abundance of planktonic larvae is expressed as the number of individuals collected per $10 \mathrm{~m}^{3}$. The different volumes filtered by the net were calculated, using equations from Wieghardt (1953) and Tranter (1967). The tows at Stn S in the Villefranche Bay (30 to 
$0 \mathrm{~m})$ were $7 \mathrm{~m}^{3}$ i the vertical tows $(200$ to $0 \mathrm{~m})$ were $48 \mathrm{~m}^{3}$. We estimated the volume of filtered sea water in the continuous tows using one flowmeter (Hydro-bios model 438110 ) situated at the center of the net and another outside the net. For each $750 \mathrm{~m}$ horizontal transect, the volume of sea water filtered was $173 \mathrm{~m}^{3}$. After each collection, the plankton was immediately fixed in $4 \%$ formaldehyde. We analyzed the samples from the stations in their entirety using a stereoscopic microscope. For this study 2 classes of larvae were isolated and counted: echinoplutei and ophioplutei. Two ophioplutei abundant in our samples, Ophiopluteus bimaculatus (Müller) and $O$. compressus (Mortensen), could not be assigned to species; these names correspond to the larval names given by Müller (1852) and Mortensen (1927).

\section{RESULTS}

\section{Distribution of echinoderm larvae in the Liguro- Provençal Basin}

The area sampled is characterized by the presence of a late-spring population of echinoderm larvae and by an early-autumn/winter population in which the larvae are more abundant. The spatial distribution of echinoderm larvae is in general marked by a decrease in the number of larval species with increasing distance from the coast, with an outer limit of distribution within 13 miles of the coast (Figs. $5 \& 6$ ). However, at the end of November and December 1984 larval abundance at offshore stations was greater than at stations nearer the coast (Fig. 7).

In samples taken in 1984 the lowest concentration of echinoderm larvae were observed in March and April and coincided with a period of abundance of Salpa fusiformis in the region (Fig. 7). In May the increase in

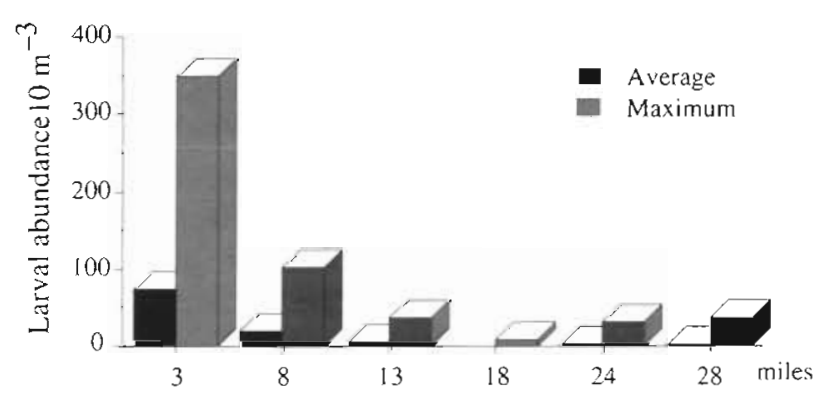

Fig. 5. Echinoderm larval abundance in samples taken along a transect from the coast to 28 miles of fshore ( 6 stations). Grey bars: maximum larval abundance tound at each station between March 1984 and February 1985. Black bars: average larval abundance for each station during 15 cruises along the

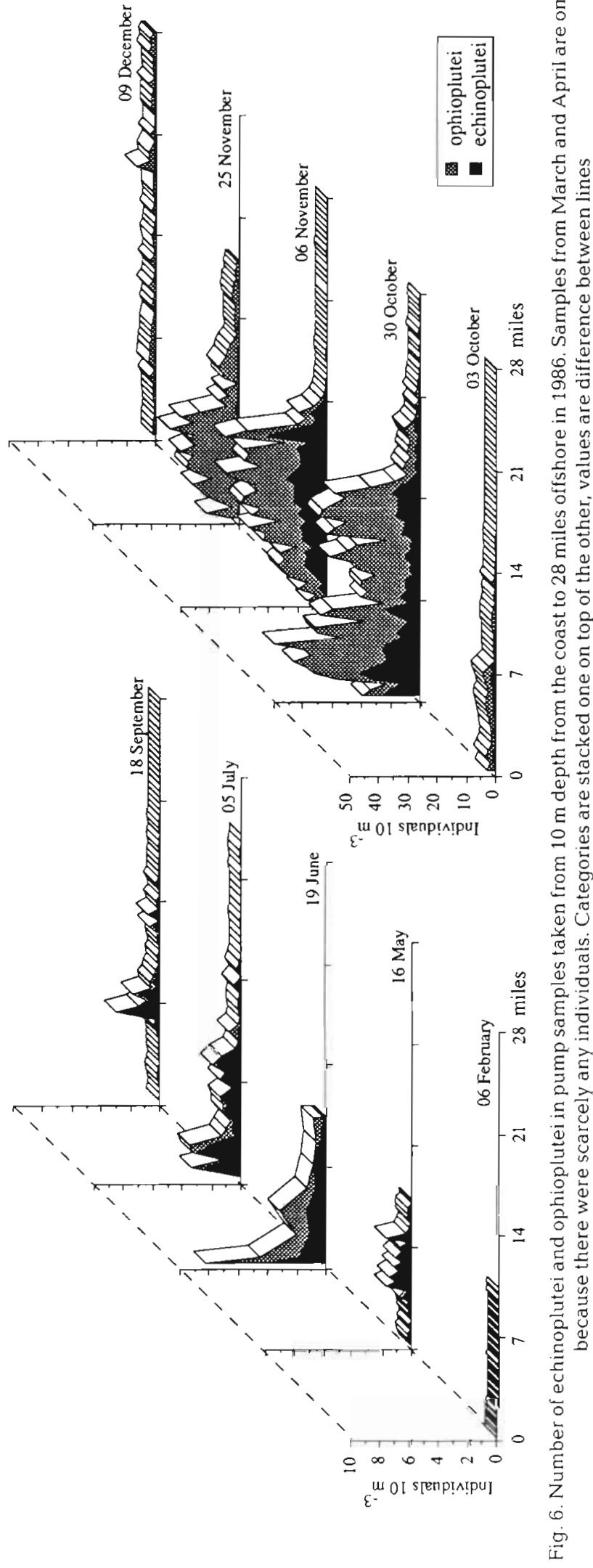
transect studied 
Fig. 7. Number of echinoplutei and ophioplutei in samples between March 1984 and February 1985, from the coast ( 3 miles) to 28 miles along the transect. Samples from 7 May are omitted because there were no individuals. Note that vertical axes are not to the same scale
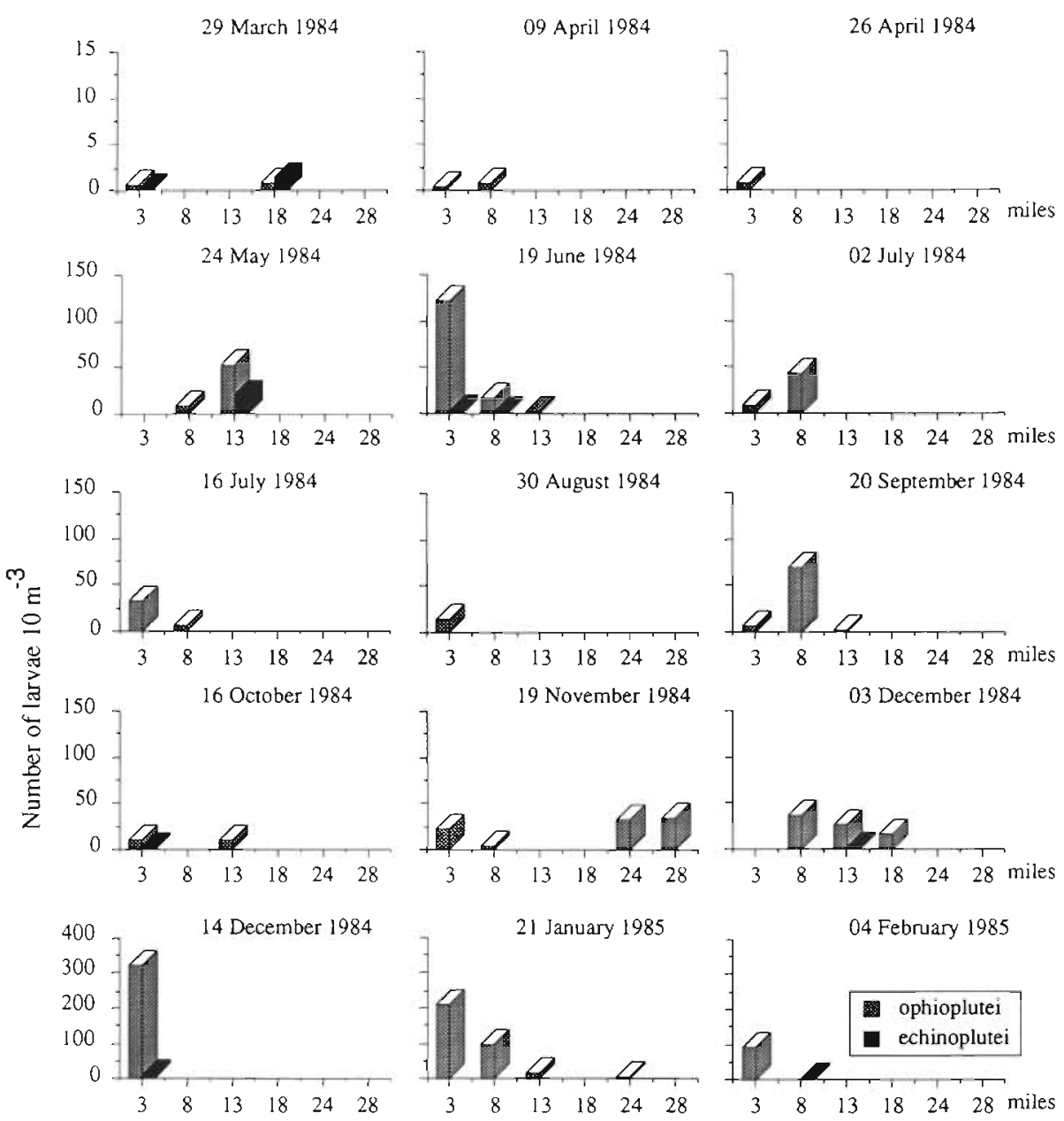

larval abundance corresponded to the presence of young Amphiura filiformis larvae and to the spawning season of Paracentrotus lividus and Arbacia Lixula. In June and July larvae become older and competent to metamorphosis. The absence of younger echinoplutei, which were abundant during the preceding month, showed that this is the end of the reproductive period for several echinoderm species. In November, very young larvae of $A$. filiformis, Ophiopluteus bimaculatus and Ophiopluteus compressus were found nearshore (3 and 8 miles, respectively) while older and competent larval stages were collected at stations far from the coast ( 23 and 28 miles). In early December post-larvae of $A$. filiformis were found at stations 18 and 28 miles offshore.

Data from horizontal continuous tows during February to April 1986 showed a paucity of plankton (Fig. 6). At the end of May spring populations of Paracentrotus lividus and Arbacia lixula appeared as in 1984. In June, more than $80 \%$ of echinoplutei of $P$. lividus had developed a rudiment. In July, A. lixula echinoplutei with 8 to 10 arms, several spatangoids, and Ophiothrix fragilis and Ophiopluteus bimaculatus larvae were abundant to 10 miles out. At the end of September and beginning of October, the postmetamorphic stages of $A$. lixula were dispersed between 7 and 17 miles. From the beginning of October to December, ophioplutei were more abundant than echinoplutei in pump samples along the transect. Young echinoplutei of $P$. lividus and $A$. lixula appeared at the end of October. Up to this time, it was possible to follow the development of a larval cohort of $P$. lividus. Early November larvae were at the 8-arm stage, and were then replaced by older stages at the end of November until the post-larval stage. Amphiura filiformis larvae, Ophiopluteus compressus and $O$. bimaculatus appeared from the end of October to the end of November. In December larvae disappeared (detailed information on spatial distribution of different larval stages of echinoderm larvae will be published elsewhere). Whatever larval stages or species, there was a drastic decrease in echinoderm larvae beyond 16 miles in continuous tows during October and November. 


\section{Biological and physical events possibly related to larval distribution}

Food supply and larval competition

To understand the mechanisms controlling larval distribution in the Ligurian Sea, several factors must be taken into account. Firstly, the temporal distribution of larval populations depends on their biological cycle, and on their functional adaptation and teleological strategies. Food supplies are distributed in the sea according to geographical area and seasonal changes. For this reason, it is complex and difficult to determine the mechanisms by which nutritional resources affect larval cycles in the field. In the Liguro-Provençal Basin, plutei find oligotrophic waters. Fenaux (unpubl.) observed that the development of a planktonic cohort of Paracentrotus lividus, followed during a phytoplankton bloom in the Bay of Villefranche in 1986, is longer than the development of larvae reared with an enriched diet. Perhaps larvae become adapted to poor environmental conditions by increasing the length of larval life. An extended planktotrophic period may increase the mortality rate by predation and the potential of dispersal and reduce chances for the larvae to return to the coastal areas of Villefranche.

The low larval concentration observed during March and April may be more related to biological interaction than to larval dispersal. Samples taken daily at Stn B in the Bay of Villefranche showed the presence of larvae of the Spatangoidea Echinocardium flavescens (Müller), Ophiopluteus compressus and Amphiura filiformis in early March 1984 (Pedrotti unpubl.). The drop in larval abundance in the middle of March at Stn B and on the transect coincided with the appearance of a bloom of Salpa fusiformis (Tunicata) in the region (Choe 1985). Due to the reproductive adaptations of salps, namely high reproduction rate (forming dense blooms) and high individual rates of growth, they can supplant other filter-feeding species (Braconnot et al. 1988).

\section{Hydrological events}

Physical parameters were measured during the same period that zooplankton were collected. In November 1984, the distribution of larvae up to 28 miles offshore was related to the physical parameters. At this time, salinity and temperature in surface waters to $50 \mathrm{~m}$ depth were nearly homogeneous from the coast to 28 miles offshore; the density front was present between 15 and 23 miles, but below $50 \mathrm{~m}$. (Fig. 8). Probably larvae could be transported offshore due to the absence of a density frontal barrier in the surface layer

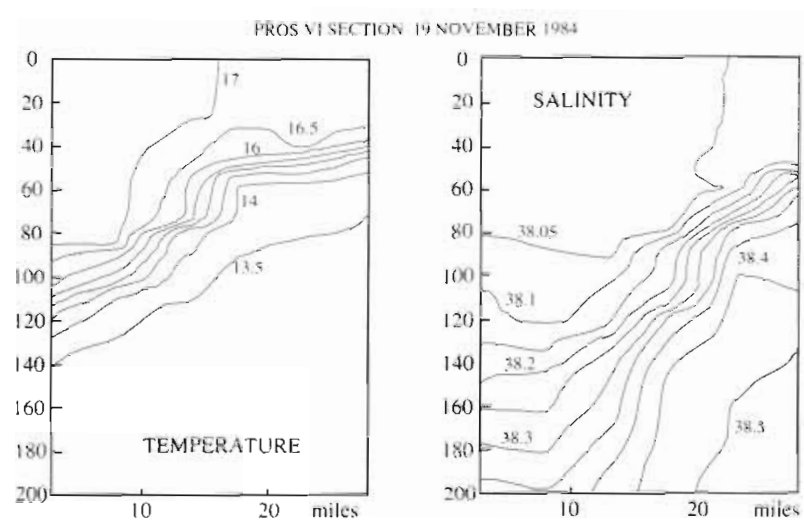

Fig. 8. Temperature and salinity on 19 November 1984, from the coast to 28 miles along the transect. Data are from the PROS Vl programme

During autumn 1986, high salinity occurred along the coast, up to between 14 and 17 miles offshore. A similar phenomena was also observed in 1957 and 1958 by Bougis \& Carré (1960) and in 1987 and 1988 by Dallot \& Pizay (1989). The following scenario may explain the succession of events. During the summer, the surface of the Liguro-Provençal Basin is the site of transformation of Atlantic waters into those of the Mediterranean which are warmer and more saline (Gostan 1968). The current which enters the region in autumn, coming from the south, has a higher temperature than the waters in the basin. The lack of rain during summer 1986 resulted in an increase in salinity of surface waters. The high evaporation rate without a decrease in air temperature resulted in a positive thermal balance. Very weak winds allowed a stable and homogeneous surface layer. The density increases from the coast (peripheral zone) to 28 miles out agree with the conceptual scheme established for this region.

The limits of larval distribution during October and November 1986 corresponded with changes in physical parameters. At the end of October, comparing stations on either side of 16 miles offshore, the number of larvae per $10 \mathrm{~m}^{3}$ dropped from 30 to 5 individuals (Fig. 6); further away no larvae were found. The surface temperature decreased from 19.80 to $18.00^{\circ} \mathrm{C}$ and salinity from 38.27 to $38.13 \%$ (Fig. 9). In November, the abundance of larvae at stations around 14 miles offshore decreased from 35 ind. per $10 \mathrm{~m}^{3}$ to 10 ind. (Fig. 6). Beyond 14 miles offshore no larvae were found. The surface water temperature decreased from 17.50 to $16.30^{\circ} \mathrm{C}$ and salinity from 38.30 to $38.14 \%$. The differences in density excess near the surface either side of 16 miles offshore in October and of 14 miles offshore in November were $0.29 \mathrm{~kg} \mathrm{~m}^{-3}$ and $0.30 \mathrm{~kg} \mathrm{~m}^{-3}$ respectively. These differences correspond to the density gradient across the front. 

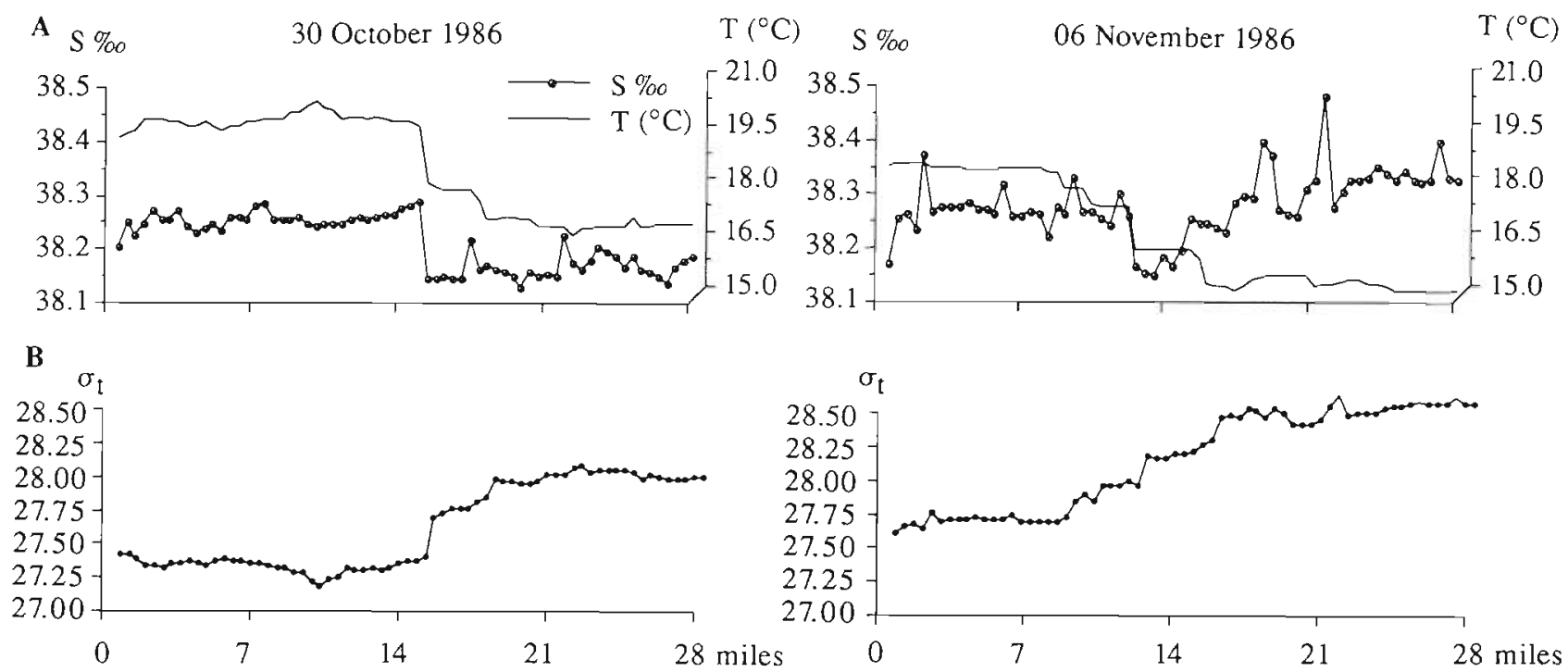

Fig. 9. (A) Salinity and temperature measured at $10 \mathrm{~m}$ depth on 30 October and 6 November 1986, from the coast to $28 \mathrm{miles}$ along the transect. (B) Density excess (sigmat- $t$ ) in $\mathrm{kg} \mathrm{m}^{-3}$ calculated from the temperature and salinity given in the upper graphs

\section{Distribution of Paracentrotus lividus larvae in the Bay of Villefranche}

The succession of the different larval stages of Paracentrotus lividus at Stn S in the Bay of Villefranche from September to December 1986 was the same as that observed along the transect. Larvae with 4 arms appeared at the end of October (Fig. 10). Larvae with 8 arms appeared in early November; the rudiment stage was collected between 7 and 19 November and postlarval stages at the end of November. Undoubtedly, advanced stages and post-larvae found in the Bay belonged to the same population. The same succession of different larval stages as found in autumn 1986 was found in 1987 (Pedrotti 1990). These results suggest

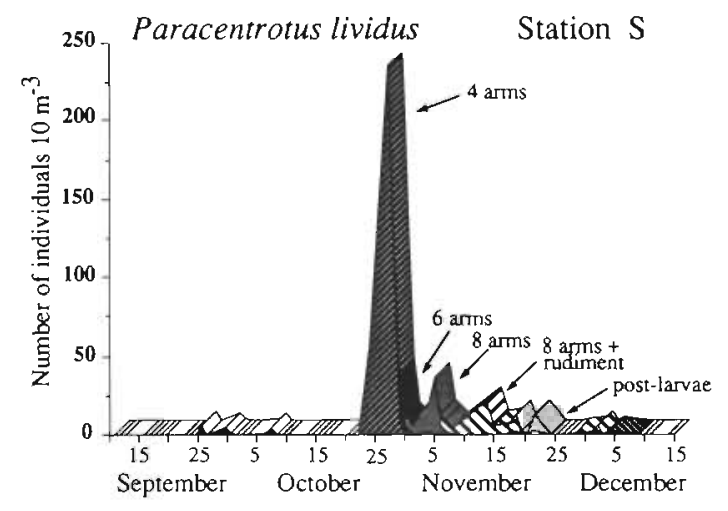

Fig. 10. Paracentrotus lividus. Different larval stages (ind. $10 \mathrm{~m}^{-3}$ in the Bay of Villefranche (Stn S) from September to December 1986 that the larvae sampled come from a simultaneous autumn spawning that favours synchronous larval development. A part of the larvae produced by the local and nearby adult populations were retained in the bay by hydrological processes. During autumn 1986, after a period at the end of October during which strong winds seem to have stimulated gamete release (Pedrotti unpubl.), there was a period in which winds became weaker. In November, easterly winds were predominant. In such conditions, the surface current entering the Bay has a reduced flow speed and the larvae can probably remain for several days trapped in the circulation by the contrary flow or by local eddies created in the surface layer (see Fig, 4).

Phytoplankton development, due to enrichment of nutritive salts, can also be a factor favoring larval development in the Bay. The Paracentrotus lividus larval. development observed at the end of May 1986 in the bay coincided with the end of the spring phytoplankton bloom (Fenaux et al. 1987). A series of continuous plankton tows made parallel to the coast between Antibes and Monaco (French Riviera) in June 1987 showed the presence of larval peaks in relation to coastal features; there were higher densities off the Bay of Angels (Nice) and off the Bay of Villefranche (Pedrotti 1990).

While hypotheses concerning physical mechanisms of larval retention can be supported by our results, predictions about how long a cohort of larvae must persist in the Bay to allow recruitment success are uncertain.

In attempting to estimate the decreasing abundance of Paracentrotus lividus larvae with stage the number of individuals in a cohort, from the appearance of 4 - 
Table 1. Paracentrotus lividus. Decrease in abundance of larvae from the day of the appearance of the 4-arm stage $(100 \%)$ to the planktonic postlarval stage (PL) at Stn S in the Bay of Villefranche. Boldface type shows highest percentage of each stage. Rud: 8 -arm stage + rudiment

\begin{tabular}{|cccccc|}
\hline Day & $\%$ 4-arm & $\%$ 6-arm & $\%$ 8-arm & $\%$ Rud & $\%$ PL \\
\hline 1 & $\mathbf{1 0 0}$ & 0 & 0 & 0 & 0 \\
2 & $\mathbf{4 9 . 7}$ & 4.2 & 0.6 & 0 & 0 \\
3 & 3.0 & $\mathbf{1 3 . 3}$ & 0.61 & 0 & 0 \\
4 & 1.2 & 1.8 & 1.8 & 0 & 0 \\
5 & 0 & 0 & 2.4 & 0 & 0 \\
8 & 0.61 & 0.61 & 7.9 & 0 & 0 \\
9 & 0 & 0 & 13.9 & 1.8 & 0 \\
10 & 0 & 0 & 2.4 & 3.0 & 0 \\
11 & 0 & 0 & 1.2 & 3.0 & 0 \\
12 & 0 & 0 & 0 & 1.8 & 0 \\
16 & 0 & 0 & 0 & 7.9 & 0 \\
17 & 0 & 0 & 0.61 & $\mathbf{8 . 5}$ & 0 \\
18 & 0 & 0 & 0 & 2.4 & 0 \\
21 & 0.61 & 0 & 0 & 2.4 & 0.6 \\
22 & 0.61 & 0 & 0.61 & 3.0 & $\mathbf{1 . 2}$ \\
23 & 0 & 0 & 0 & 0 & $\mathbf{1 . 2}$ \\
\hline
\end{tabular}

arm stages to the appearance of post-larval stages, was followed regularly at Stn S in the Bay of Villefranche. Taking the 4 -arm stages as $100 \%$, only $1.2 \%$ postlarval stages were observed after $23 \mathrm{~d}$ (Table 1 ). If one considers that the larvae sampled come from the same spawning originating in local coastal Villefranche populations and that a part of them are retained in the bay by the biological and physical mechanisms described above, the local density of older larval stages corresponds closely to recruitment. The decrease probably corresponds to mortality and dispersal. The decrease in larval abundance is often falsely attributed principally to mortality, as pointed out by Strathmann (1985). Even if the mortality rate in the field is considered to be very high (Vance 1973a, b, Chia 1974), the role of dispersal in population dilution is also important. The estimation of the mortality rate becomes valid if it is made on populations having synchronous gamete batches and where advective and diffusion transport can be estimated (Korringa 1952).

\section{DISCUSSION}

\section{Larval distribution perpendicular to the coast}

Boucher et al. (1987) studied the space-time microdistribution of zooplankton in relation to hydrological phenomena in the Ligurian Sea. This first study classed echinoderm larvae as a group belonging strictly to coastal areas and corresponding to the maxima of spring biomass. The frontal zone was considered as the offshore boundary which is not crossed by neritic species. Our results show, however, that larvae and post-larvae display a great potential for dispersal and their distribution is directly associated with variations in regional hydrological phenomena. The larvae and post-larvae of echinoderms, which have no ontogenetic migration, a diel vertical migration of a few meters and a slow swimming rate (Banse 1964, 1986, Pennington \& Emlet 1986, Pedrotti 1990), may act like passive particles subjected to hydrodynamic controls associated with surface waters. Currents sometimes represent barriers to dispersal; sometimes they may enhance larval dispersal (Scheltema 1988, Scheltema \& Rice 1990), transporting them away from favorable sites for settlement and juvenile growth.

In the studied region, at the end of November 1984 , when the extension of the Ligurian Current is maximal, larvae were observed as far out as 28 miles, at the transect station furthest from Villefranche. Two hypotheses could explain larval presence at 28 miles: (1) the front does not manifest itself at the surface during this period, and no barrier exists to limit the offshore extent of larval dispersion (2) during autumn there is a gradual transition between the coastal system (Ligurian Current) and the system in the open sea (Bong 1983) due probably to eddies resulting from instabilities in the surface layer of the current, where echinoderms are present (Louis Prieur pers. comm.). In the absence of discontinuities of physical parameters larvae are transported by the mainstream of the current to the open sea. Hence, the numbers of individuals recruited in the areas where adults are found will be reduced.

In October and beginning of November of 1986, during the spawning autumn season, the limits of larval distribution corresponded with a hydrodynamic barrier. The presence of a coastal divergence zone, where there is an upwelling of subsurface waters, most likely limits the larval distribution in the Ligurian Current. A schematic drawing showing horizontal larval distribution and hydrological conditions during autumn 1986 is given in Fig, 11: larvae are distributed up to 16 miles out. This distance coincides with the edge of the Ligurian Current. The stratification of the water column keeps larval distribution near the surface waters in autumn

Contrary phenomena were observed by Pedrotti (1990) during winter 1986. At this time, due to the vertical mixing of the water column, larvae are passively transported from the surface layers downward according to patterns of circulation. Larvae that are weak swimmers and that do not migrate vertically are incapable of traversing discontinuities, and hydrodynamics alone can explain the presence of the larvae at depth. 


\section{Recruitment chances for larvae found further offshore}

How do larvae return to the coastal regions after being dispersed to open waters?

The most important mode of transport shoreward of the megalopae of the crab Pachygrapsus crassipes is via surface slicks associated with tidal internal waves (Shanks 1985). This transport is also the means by which some other benthic invertebrate pelagic larvae return to the coast (Shanks 1983, 1986, Shanks \& Wright 1987). In the Ligurian Sea tides are negligible and the bottom depths do not intervene in the circulation of the water masses; it is unlikely that larvae could be transported shoreward by such a mechanism. A wind-driven surface water mechanism, as found by Emlet (1986) in East Sound (Washington, USA) to transport advanced larval stages of Dendraster excentricus to adult habitats, is equally unlikely. In the studied area, the direction and intensity of the wind contribute to the circulation near the coast (in the Bay of Villefranche), but play little part in the cyclonic circulation of the Basin.

Besides favorable conditions for larval retention observed in the Bay of Villefranche we cannot hypothesize about the development of echinoderm populations found near the coast due to the presence of the Ligurian Current. Along the coast, the Ligurian Current has a complicated circulation, forming meanders with possible upwelling near the coast due to secondary circulation (Sournia et al. 1990; Fig. 2). Those larvae found in the vortices will have better chances of being transported to nursery zones, probably in bays. In comparison, plutei found in the main flux of the Ligurian Current (2000 $\mathrm{m}$ depth) or transported to the open sea will probably not return to the same coastal

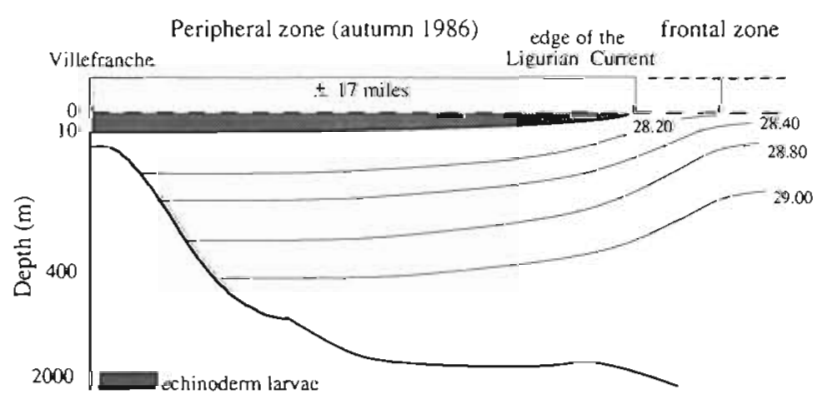

Fig. 11. Vertical section from the coast to offshore, showing larval distribution and hydrological conditions during autumn 1986. Larvae are distributed up to 16 miles out. This distance coincides with the coastal divergence zone, where there is an upwelling of subsurface waters, and this most likely limits the larval distribution in the Ligurian Current. The density excesses (sigma-t) in $\mathrm{kg} \mathrm{m}^{-3}$ were obtained from the PROS VI (Prieur et al. 1990) programme

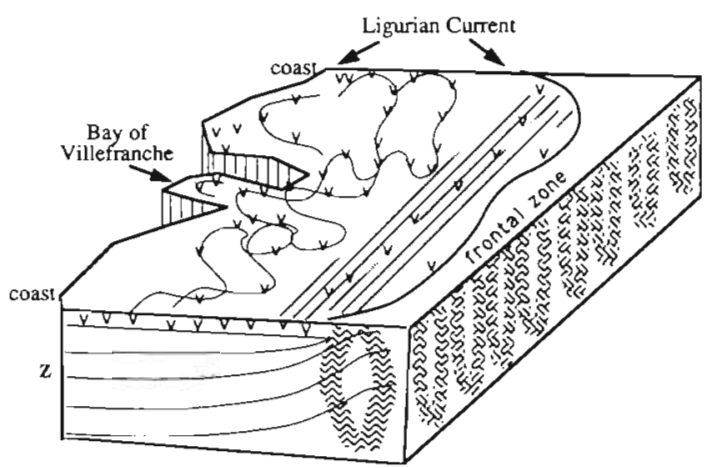

Fig. 12. Schema showing the possible trajectory of larvae in the Ligurian Current during autumn 1986. Along the coast, meanders are formed, whereas in the open sea, the current is much stronger. Larvae found in the meanders will have the best recruitment chances

regions. They must prolong their larval period until finding favorable recruitment sites (Fig. 12). The presence in November 1986 of larvae further out which are older than those found on the coast suggests that larvae delay metamorphosis. This problem is posed for competent larvae of the infra-littoral species Arbacia lixula and Paracentrotus lividus, for which the greatest depths of distribution in the Mediterranean sea are 40 and $80 \mathrm{~m}$, respectively. In the laboratory, echinoplutei of $P$. lividus can delay metamorphosis for $53 \mathrm{~d}$ after reaching competence (Pedrotti 1990), but it is unknown how long larvae maintain competence in the field. Even if metamorphosis takes place before settling (Fenaux \& Pedrotti 1988), the post-larvae now find themselves in a hostile environment and thus this part of the population may be considered lost for benthic recruitment. The ophiuroid larvae studied have better chances of recruitment. They have a planktonic life span longer than that of the echinoids (Pedrotti 1990). Metamorphosis precedes settling onto a surface and these species are found at greater depths. However, according to Gage \& Tyler (1981), post-larval stages of the upper-bathyal Ophiocten gracilis, found at $2900 \mathrm{~m}$ depth, are the consequence of dispersal to non-favorable regions, and this represents a loss for recruitment.

Coastal upwelling, according to its variation and intensity, may have a favorable or unfavorable effect on larval transport in the surface waters. Along the coasts of California and Oregon (USA), intense upwelling advects competent larvae of the purple sea urchin Strongylocentrus purpuratus away from the coast while eddies that form due to the cold water jets may bring larvae back to the coast (Ebert \& Russell 1988). In the California and Peru currents, upwelling and its associated offshore transport acting previous to spawning activity might enhance larval survival by ensuring adequate 
food particle concentrations, and acting at the same spatio-temporal scales as spawning could result in an offshore loss of eggs and larvae (Bakun \& Parrish 1982). In the Ligurian Sea, the presence of a density front in surface waters limits larval dispersal, while its absence enhances the offshore transport of larvae.

The present study emphasizes the importance of knowledge of physical processes in coastal regions to understanding the ecology of larval echinoderms. The influence of a hydrological barrier in distribution and dispersal of echinoderm larvae raises questions about the dynamics of other coastal meroplankton populations in the Ligurian Sea. One may hypothesize that the relationship between upwelling intensity and larval production may be an important factor that determines success in recruitment. However, the way by which competent echinoderm larvae leave surface waters to settle on the bottom still remains unknown. A close survey of larvae near the bottom and a good description of circulation and mixing processes through the water column are needed to elucidate this question.

Acknowledgements. We thank L. Prieur, S. Dallot, P. Nival, M. Youngbluth, R. Scheltema and anonymous reviewers for constructive comments, and A. M. Corre for help with plankton sample analysis. This work was supported by CNRS-UA 716 and FRONTAL (JGOFS/France) and PNDR programmes.

\section{LITERATURE CITED}

Bakun, A., Parrish, R. H. (1982). Turbulence, transport, and pelagic fish in the California and Peru current systems. CalCOFI Rep. XXXIII: $99-112$

Banse, K. (1964). On the vertical distribution of zooplankton in the sea, Prog. Oceanogr. 2: 53-125

Banse, K. (1986). Vertical distribution and horizontal transport of planktonic larvae of echinoderms and benthic polychaetes in an open coastal sea. Bull. mar. Sci. 39(2): 162-175

Bethoux, J. P., Nyffeler, F., Prieur, L. (1981). Utilisation des moyennes hydrologiques pour le calcul des flux d'eaux dans le bassin Liguro-provençal. Rapp. comm. int. mer Med. 27(6): 193-196

Bethoux, J. P., Prieur, L. (1983). Hydrologie et circulation en Méditerranée Nord-Occidentale. Pétrole et techniques 229: $24-34$

Bethoux, J. P., Prieur, L., Bong, J. H. (1988). Le courant Ligure au large de Nice. Oceanol. Acta 9: 59-67

Bong, J. H. (1983). Contribution à l'étude du courant Ligure et de sa variabilité spatio-temporelle à moyennes échelles. Thèse 3ème cycle, océanographie physique, Univ. Paris

Boucher, J. (1984). Localization of zooplankton population in the Ligurian marine front: role of ontogenic migration. Deep Sea Res. 31(5): 469-484

Boucher, J., Ibanez, F., Prieur, L. (1987). Daily and seasonal variations in the spatial distribution of zooplankton population in relation to the physical structure in the Ligurian Sea Front. J. mar. Res. 45: 133-173

Bougis, P., Carré, C. (1960). Conditions hydrologiques à Villefranche-sur-Mer pendant les années 1957-1958. Cahiers océan. 12(6): 393-408
Braconnot, J. C., Choe, S. M., Nival, P. (1988). La croissance et le développement de Salpa fusiformis Cuvier (Tunicata, Thaliacea). Ann. Inst. oceanogr. Paris 64: 101-114

Chia, F. S. (1974). Classification and adaptative significance of developmental patterns in marine invertebrates. Thalassia jugosl. 10(1/2): 121-130

Choe, S. M. (1985). Contribution à l'étude biologique et écologique des Tunicens pélagiques SaIpides (Thaliaces) en Méditerranée. Thèse de doctorat 3ème cycle. Univ. Paris VI

Dallot, S., Pizay, M. D. (1989). Changement des conditions hydrologiques en mer Ligure entre mars 1988 et mars 1989. [n: L'Helgven, S. (ed.) Devenir de la matière organique produite dans les zones frontales, consommation, minéralisation exportation, importance des phénomènes physiques. 'Table Ronde' Frontal, INSV, Brest, 1 p.

Ebert, T. A., Russel, M. P. (1988). Latudinal variation in size structure of the west coast purple urchin: a correlation with headlands. Limnol. Oceanogr. 33(2): 286-294

Emlet, R. B. (1986). Larval production, dispersal, and growth in a fjord: a case study on larvae of sand dollar Dendraster excentricus. Mar. Ecol. Prog. Ser. 31: 245-254

Fenaux, L., Claustre, H., Cellario, C. (1987). Développement larvaire de Paracentrotus lividus (Larmak) dans des conditions de bloom phytoplanctonique. In: $5^{\text {e }}$ Séminaire International des Échinodermes actuels et fossils. Bull. Soc. Sci. nat. Ouest France, Suppl. hors-série, p. 83 (abstract)

Fenaux, L., Pedrotti, M. L. (1988). Métamorphose des larves d'Echinides en pleine eau. P.S.Z.N. I: Mar. Ecol. 9(2): 93-107

Gage, J. D., Tyler, P. A. (1981). Non-viable seasonal settlement of larvae of the upper bathyal brittle star Ophiocten gracilis in the Rockall Trough abyssal. Mar. Biol. 64: $153-161$

Gascard, J. C. (1991). Open ocean convection and deep water formation revisited in the Mediterranean, Labrador, Greenland and Weddel seas. In: Chu, P. C., Gascard, J. C. (eds.) Deep convection and deep water formation in the oceans. Elsevier, Oceanographic Series 57, p $157-181$

Gostan, J. (1968). Contribution à l'étude hydrologique du bassin Liguro-provençal entre la Riviera et la Corse. Thèse doctorat Etat, fac. sci. Univ. Paris

Greenblatt, P. R. (1982). Small-scale horizontal distributions of zooplankton taxa. Mar. Biol. 67: 97-11

Haury, L. R. (1976). Small-scale pattern of a California current zooplankton assemblage. Mar. Biol. 37. 137-157

Haury, L. R., McGowan, J. A., Wiebe, P. H. (1978). Patterns and processes in the time-space scales of planktonic distributions. In: Steele, J. H. (ed.) Spatial pattern in plankton communities. Plenum Press, New York, p. 277-327

Haury, L. R., Wiebe, P. H. (1982). Fine-scale multi-species aggregation of oceanic zooplankton. Deep Sea Res. 29(7A): $915-921$

Hentsch, J. M. (1959). Etude des courants de la Baie de Villefranche. Master's thesis, Université de Paris

Korringa, P. (1952). Recent advances in oyster biology. Q. Rev Biol. 27: 266-308 \& 339-365

Mackas, D. L., Denman, K. L., Abbott, M. K. (1985). Plankton patchiness: biology in the physical vernacular. Bull. mar Sci. 37(2): 652-674

Mileykovsky, S. A. (1966). Range of dispersion of the pelagic larvae of benthic invertebrates by currents and the migratory role of this dispersion taking Gastropoda and Lamellibranchia as examples. Oceanology 6(3) $396-404$ 
Mileikovsky, S. A. (1968). Some common features in the drift of pelagic larvae and juvenile stages of bottom invertebrates with marine currents in temperate regions. Sarsia 34: 209-216

Mileikovsky, S. A. (1970). Seasonal and daily dynamics in pelagic larvae of marine shelf bottom invertebrates in nearshore waters of Kandalaksa Bay (White Sea). Mar. Biol. 5: 180-194

Mileikovsky, S. A. (1971). Types of larvae development in marine botton invertebrates, their distribution and ecological significance: a re-evaluation. Mar. Biol. 10(3): 193-213

Mileikovsky, S. A. (1974). Types of larval development in marine botton invertebrates: an integrate ecological scheme. Thalassia jugosl. 10(1/2): 171-179

Mortensen, Th. (1927). Handbook of the echinoderms of the British Isles. Oxford Univ. Press, Oxford

Müller, J. (1852). Über die Ophiurenlarve des Adriatischen Meeres. Dümmler, Berlin

Nival, P., Malara, G., Chara, R. (1975). Evolution du plancton dans la baie de Villefranche-sur-Mer à la fin du printemps (mai et juin 1971). I. Hydrologie, sels nutritifs, chlorophylle. Vie Milieu 25(2): 231-260

Okubo, A. (1980). Diffusion and ecological problems: mathematical models. Biomathematics, Vol. 10. Springer-Verlag, Berlin, p. 25-42

Pedrotti, M. L. (1990). Etude des processus biologiques et facteurs physiques responsables de la dispersion et du recrutement des larves méroplanctoniques. Modèle: les larves d'Echinodermes. Thèse de doctorat de l'Université Pierre et Marie Curie en Sciences de la Vie, Paris

Pennington, $J$ T., Emlet, R. B. (1986). Ontogenetic and diel migration of a planktonic echinoid larva Dendraster excentricus (Eschscholtz): occurrence, causes and probable consequences. J. exp. mar. Biol. Ecol. 104: 69-95

Prieur, L. (1981). Hétérogénéité spatio-temporelle dans le bassin Liguro-provençal. Rapp. Comm. int. mer Med. 27(6): $177-179$

Prieur, L., Raunet, J., Taillez, D. (1990). Radiale PROS VI 1981-1989. Rapport interne L.P.C.M. (Laboratoire de Physique et Chimie Marines). CNRS, Villefranche-surMer

Shanks, A. I. (1983). Surface slicks associated with tidally forced internal waves may transport pelagic larvae of benthic invertebrates and fishes shoreward. Mar. Ecol. Prog. Ser 13: 311-315

Shanks, A. L. (1985). Behavioral basis of internal-waveinduced shoreward transport of megalopae of the crab Pachygrapsus crassipes. Mar. Ecol. Prog. Ser. 24: 289-295

Shanks, A. L. (1986). Tidal periodicity in the daily settlement. of intertidal barnacle larvae and a hypothesized mechanism for the cross-shelf transport of cyprids. Biol. Bull. 170: $429-440$

Shanks, A. L., Wright, W. G. (1987). Internal wave mediated shoreward transport of cyprids megalopae, and gammarids and correlated longshore differences in the settling rate of intertidal barnacles. J exp. mar. Biol. Ecol. 114: $1-13$

Scheltema, R. S. (1966). Evidence for trans-Atlantic transport of gastropod larvae belonging to the genus Cymatium. Deep Sea Res. 13: 83-95

This article was presented by R. S. Scheltema, Woods Hole, Massachusetts, USA
Scheltema, R. S. (1968). Dispersal of larvae by equatorial ocean currents and its importance to the zoogeography of shoal-water tropical species. Nature, Lond 217: 1159-1162

Scheltema, R. S. (1971). The dispersal of the larvae of shoalwater benthic invertebrate species over long distances by ocean currents. In: Crisp, D. J. (ed.) Proc. 4 th Eur. Mar. Biol. Symp. Cambridge Univ. Press, London, p. 7-28

Scheltema, R. S. (1972). Dispersal of larvae as a means of genetic exchange between widely separated populations of shoal-water benthic invertebrate species. In: Battaglia, B. (ed.) Proc. 5th Eur. Mar. Biol. Symp. Piccin, Padua, p. $101-144$

Scheltema, R. S. (1974). Biological interactions determining larval settlement of marine invertebrates. Thalassia jugosl. 10(1/2): 263-296

Scheltema, R. S. (1975). The frequency of long-distance larval dispersal and the rate of gene-flow between widely separated population of sipunculans. In: Rice, M. E., Todorović, M. (eds.) Proc. of International Symposium on the Biology of the Sipuncula and Echiuna, Vol. 1. Institute for Biological Research, Belgrade, and National Museum of Natural History, Smithsonian Institution, Washington, D.C., p. $18-25$

Scheltema, R. S. (1986). On dispersal and planktonic larvae of benthic invertebrates: an eclectic overview and summary of problems. Bull. mar. Sci, 39(2): 290-322

Scheltema, R. S. (1988). Initial evidence for the transport of teleplanic larvae of benthic invertebrates across the east Pacific Barrier. Biol. Bull. 174: 145-152

Scheltema, R. S., Rice, M. E. (1990). Occurrence of teleplanic pelagosphera larvae of sipunculans in tropical regions of the Pacific and Indian oceans. Bull. mar. Sci. 47(1): $159-181$

Sournia, A., Brylinsky, J. -M., Dallot, S., Le Corre, P., Levau, M., Prieur, L., Froget, C. (1990). Fronts hydrologiques au large des côtes françaises: les sites-atelies du programme Frontal. Oceanol. Acta 13: 413-438

Strathmann, R. R. (1975). Larval feeding in echinoderms. Am. Zool. 15: 717-730

Thorson, G. (1961). Length of pelagic larval life in marine bottom invertebrates as related to larval transport by ocean currents. In: Sears, M. (ed.) Oceanography. Am. Ass. Advmt. Sci., Washington, D.C., 67:455-474

Tranter, D. J. (1967). A formula for the filtration coefficient of a plankton net. Aust. J. mar. Freshwat. Res. 1. 113-121

Vance, R. R. (1973a). On reproductive strategies in marine benthic invertebrates. Am. Nat. 107: 339-351

Vance, R. R. (1973b). More on reproductive strategies in marine benthic invertebrates. Am. Nat. 107: 353-361

Wieghardt, K. E. G. (1953). On the resistance of screens. Aeronaut. Q. 4: 186-172

Yamamoto, T., Nishizawa, S. (1986). Small-scale zooplankton aggregations at the front of a Kuroshio warm-core ring. Deep Sea Res. 33(11/12): 1729-1740

Young, C. M, Chia, F. (1987). Abundance and distribution of pelagic larvae as influenced by predation, behavior, and hydrographic factors. In: Giese, A., Pearse, J., Pearse, V. B. (eds.) Reproduction of marine invertebrates, Vol. 9. Blackwell Sci. Publ., Palo Alto, California, p. 385-463

Manuscript first received: December 5, 1991

Revised version accepted: June 25, 1992 